\title{
Histochemical Changes in Developing Mouse Liver after Administration of Phenobarbital 1,2
}

\author{
THOMAS C. RICHARDS 3 \\ Department of Anatomy, University of Michigan, \\ Ann Arbor, Michigan 48104
}

\begin{abstract}
The effects of phenobarbital on development of some microsomal enzymes and neutral lipid were studied in mouse liver during a period of rapid cell differentiation. Specific alterations attributable to phenobarbital were identified in developing liver and used as markers for the onset of certain aspects of cell maturation. This investigation was designed to determine (1) the earliest developmental age at which fetal liver can react to phenobarbital and (2) the nature of the alterations in developing and adult liver.

Intraperitoneal injections of phenobarbital were given for three days to 14 , 17 and 19 day pregnant mice. Histochemical techniques were used to localize neutral lipid and the activities of NADPH diaphorase, glucose-6-phosphatase, and glucose-6-phosphate dehydrogenase. Total cell lipid was measured in livers from 17- and 19-day pregnant mice and livers from their fetuses.

The density of reaction product for NADPH diaphorase and glucose-6-phosphate dehydrogenase increased while glucose-6-phosphatase decreased in adult liver. Similar changes were seen in livers from day-19 fetal animals but not in fetuses of younger ages. Neutral lipid droplets increased in size and number after phenobarbital in fetal mice of day 19 of gestation but not in mice of day 17 of gestation.

It was concluded that liver from day-19 fetal mice had gained the competence, lacking in earlier ages, to respond to phenobarbital by increased production of some enzymes and neutral lipid.
\end{abstract}

Differentiation of mammalian liver is in part a process by which fetal cells progressively attain chemical and structural profiles similar to mature cells. The gradual acquisition of cellular components and the onset of functional capabilities are correlated (Dallner et al., '66a,b); therefore, the capacity of the fetal liver to perform different metabolic processes broadens as development proceeds. The degree of differentiation of fetal liver at a particular time during development could be defined by its competence to respond to an external stimulus such as a drug.

The barbiturate, phenobarbital, has been shown to be a powerful inducer of some microsomal enzymes (Conney and Burns, '63; Orrenius et al., '65) and to have a stimulatory effect on the synthesis of smooth endoplasmic reticulum in adult liver of several species (Jones and Fawcett, '66). The drug stimulates microsomal phospholipid synthesis (Holtzman and GiI- lette, '66) and increases stored neutral lipid within the cells (Salvador et al., '70).

Phenobarbital passes across the placenta rapidly and in unaltered form (Fouts, '65; Dixon and Willson, '68); therefore, fetuses in utero are exposed to phenobarbital administered to the pregnant mother. Identification of specific alterations in fetal liver, attributable to phenobarbital, which are known to occur in the adult provides a valid test of the responsiveness of the fetal cells, if it is postulated that the ability of the fetal liver to respond to the drug is related to its degree of differentiation.

In this report emphasis has been placed on identification of histochemical changes

\footnotetext{
1 Part of a dissertation submitted to the Horace $\mathbf{H}$. Rackham School of Graduate Studies of the University of Michigan in partial fulfillment of the requirement for the degree of Doctor of Philosophy.

2 Supported by N.I.H. grant GM 00312, Department of Anatomy, The University of Michigan, Ann Arbor, Michigan 48104.

3 Present address: Department of Anatomy, University of Oregon Medical School, Portland, Oregon 97201.
} 
in enzymes associated with smooth endoplasmic reticulum in adult and developing mouse liver and on histochemical and quantitative changes in neutral lipid in liver. The enzymes chosen for study were NADPH diaphorase, glucose-6-phosphate dehydrogenase, and glucose-6-phosphatase. This study was designed to investigate (1) histochemical differences in enzyme patterns in adult mouse liver from phenobarbital-treated and control animals, (2) the age of the developing liver at which phenobarbital-induced changes are first identifiable and (3) the nature of the phenobarbital-induced alterations in fetal liver.

\section{MATERIALS AND METHODS}

White female mice of the Swiss WebsterRoswell Park strain were used. One male of the same stock was caged overnight with four females and the morning of finding a vaginal plug was counted as day one of pregnancy in a 20-day gestation period. Livers from fetuses and their mothers on days 14,17 , and 19 of gestation as well as livers from non-pregnant females were used in the study. The adult females were injected intraperitoneally with 100 $\mathrm{mg} / \mathrm{kg}$ of phenobarbital or with $0.9 \% \mathrm{NaCl}$ once daily for three days prior to the morning of sacrifice.

The animals were killed by cervical dislocation and the livers were quickly excised, rinsed in cold saline and lightly blotted dry. Portions of the left lateral lobe were prepared for histochemical analysis by freezing the tissue with a drop of water to a cryostat tissue holder which had been cooled with an acetone-dry ice mixture $\left(-70^{\circ} \mathrm{C}\right)$. The remainder of the liver was utilized for quantification of lipid.

All sections were cut at $10 \mu$. The sections were melted onto warm coverslips and air-dried for 5 to 30 minutes before incubation in selected substrates. The following enzymes were studied: NADPH diaphorase (Conklin, '66), glucose-6-phosphatase (Washstein and Meisel, '56) and glucose-6-phosphate dehydrogenase (Karnovsky and Himmelhoch, '61).

In the method for NADPH diaphorase, the sections were prefixed in $4^{\circ} \mathrm{C}$ calcium formol for $10-15$ seconds. The sections for the glucose-6-phosphate dehydrogenase method were dipped in $4^{\circ} \mathrm{C}$ acetone for
20-30 seconds prior to incubation. The incubation procedure for NADPH diaphorase was five minutes and 15 minutes for sections of adult and fetal liver, respectively. Sections of both adult and fetal liver were incubated either 15 minutes for the glucose-6-phosphatase method or 40 minutes for the glucose-6-phosphate dehydrogenase method. All sections were incubated at $37^{\circ} \mathrm{C}$. After incubation the sections were post-fixed in either calciumformol (NADPH diaphorase and glucose-6phosphate dehydrogenase) or $10 \%$ neutral buffered formalin (glucose-6-phosphatase). The sections were mounted in glycerin jelly.

Intracellular neutral lipid was localized by using the oil red O-isopropanol technique of Lillie ('44). Control sections, which were placed in oil red $O$ after a five minute wash in acetone, displayed negative staining. The sections were counterstained in Ehrlich's acid alum hematoxylin for five minutes, dipped in ammonium hydroxide, postfixed in $4^{\circ} \mathrm{C}$ calcium-formol for ten minutes and mounted in glycerin jelly.

The amount of total cellular lipid was determined in the liver from fetal mice and their mothers on days 17 and 19 of gestation, as well as in liver from nonpregnant adult females. Fetal liver samples were pooled by litter. Tissue samples of approximately $1.25 \mathrm{gm}$ of adult liver and $500 \mathrm{mg}$ of fetal liver were delivered through a size 18 needle into a $25 \mathrm{ml}$ or $10 \mathrm{ml}$ volumetric flask which had been rinsed with acetone, dried and weighed. Ten and $5 \mathrm{ml}$ volumes of acetone were added to the $25 \mathrm{ml}$ and $10 \mathrm{ml}$ flasks, respectively.

A two-holed rubber stopper equipped with a capillary tube in one hole was fitted into each flask. The flasks were clamped in a water-bath at $35^{\circ} \mathrm{C}$ and $\mathrm{N}_{2}$ gas was admitted through the tube. When the liver appeared dry the flasks were removed, their outside rinsed with acetone, and dried with a clean cloth. The flasks were placed in a vacuum desiccator for one hour, removed and weighed. The difference between the preliminary weight and final weight of each flask is the dry weight of the sample (Sperry, ${ }^{\circ} 55$ ).

Immediately after the dry weight was 
determined, the flask was partially filled with chloroform : methanol solvent $(2: 1$ by volume), the dried tissue was loosened from the bottom and the flask filled to volume with additional solvent. The suspension was mixed and filtered into a glass-stoppered test tube. Five milliliter aliquots of this crude extract were purified by the technique of Folch et al. ('57).

The purified extract was transferred to preweighed volumetric flasks $(10 \mathrm{ml})$. The flasks were filled to volume with additional chloroform: methanol (2:1), placed in a water bath at $35^{\circ} \mathrm{C}$, and the solvent evaporated off with a stream of nitrogen. The flasks were transferred to a desiccator for one hour, then rinsed with acetone and weighed. The difference in flask weights represents the total cellular lipid in a $5 \mathrm{ml}$ aliquot of crude extract.

\section{RESULTS}

Histochemical analyses of adult mouse liver revealed that each enzyme studied was distributed within the hepatic lobule in a unique pattern. Reference is made to the inner zone of the lobule or cells around the central vein as pericentral and to the outer zone of the lobule or cells around the portal triads as periportal. Qualitative and semi-quantitative visual comparisons were made between liver sections from animals of the same age, one of which had received phenobarbital and one of which had received saline (control). In each histochemical procedure the liver sections from the control and phenobarbitaltreated animals were handled identically. Those used in these comparisons were placed side by side in the same substrate and were incubated for the same length of time. All comparisons were made at the same magnification after the sections had been mounted.

NADPH diaphorase. The reaction product (diformazan) of the diaphorase activity was present in adult mouse liver from control animals in moderate to dense amounts in the pericentral cells while periportal cells contained less product (fig. 1). In contrast, in liver from animals treated with phenobarbital almost all cells within the hepatic lobules except those at the periphery contained dense deposits of diformazan reaction product (fig. 2).

This enzyme was present in scanty amounts in liver from fetal animals younger than day 19 of gesetation. Diformazan deposits of the diaphorase were of moderate density in liver from day-19 fetal control mice. Reactivity was not uniform throughout the section; rather selected cells contained moderate amounts of reaction product while most cells demonstrated little activity (fig. 3). A similar situation was apparent in the phenobarbital-treated animals with the exception that more cells exhibited enzyme activity and those which were active had more intense deposits of final reaction product than in comparable controls (fig. 4).

Glucose-6-phosphatase. Histochemical analysis of glucose-6-phosphatase in adult mouse liver revealed that the active cells were clearly localized in the outer zone of the Iobule away from the central vein (figs. $5,6)$. The intensely reactive cells formed a dark band, several cells wide, around the periphery of each hepatic lobule. The cytoplasm of these cells was completely filled with dense deposits of lead sulfide. In contrast, cells next to the central vein exhibited only slight activity. Differences in glucose-6-phosphatase activity between phenobarbital-treated and control animals became apparent when comparisons in the width of the band of intensely reactive cells and the overall activity of the lobules were made (figs. 5, 6).

Glucose-6-phosphatase activity could not be demonstrated in fetal liver from phenobarbital-treated or control animals of days 14 or 17 of gestation. In liver from animals of day 19 of gestation enzyme reaction product was observed in scattered cells throughout the sections. Enzyme activity was markedly greater in liver sections from fetal control animals (fig. 7) than in liver sections from fetal animals which had been subjected to phenobarbital (fig. 8).

Glucose-6-phosphate dehydrogenase. This enzyme was localized in the liver lobule of adult mice in a pattern similar to that of NADPH diaphorase. Glucose6-phosphate dehydrogenase activity was observed in most cells throughout the liver lobule but the more intensely reactive cells 
were those next to the central vein. Diformazan deposits completely filled the cytoplasm of many pericentral cells (fig. 9). Observation of liver sections from phenobarbital-treated animals demonstrated that administration of the drug resulted in marked increases in enzymatic activity in cells throughout the lobule, especially in the pericentral cells (fig. 10).

Glucose-6-phosphate dehydrogenase was present in fetal liver on day 14 of gestation but neither the activity nor distribution of the enzyme was altered by phenobarbital. However, at one day before birth, day 19 of gestation, phenobarbital treatment dramatically increased the amount of glucose-6-phosphate dehydrogenase (figs. 11, 12). In liver sections of phenobarbitaltreated animals many cells contained dense deposits of diformazan.

Lipid. Neutral lipid droplets which appeared as discrete dots were present in the cytoplasm of almost every cell in a section of liver from the adult mouse. The droplets, which were moderate to large in size, were not present in a consistent pattern. In many cells the entire cytoplasm was filled with lipid (fig. 13). In contrast, pericentral cells of liver from adult mice treated with phenobarbital were devoid of lipid droplets but periportal cells contained heavy accumulations of lipid droplets (fig. 14).

Lipid was present in liver of all fetal ages studied. Localization of the lipid droplets within the hepatocytes of early fetal liver was obscured by the great number of hematopoietic cells. In liver from mice on day 19 of gestation lipid droplets could be seen easily but they were not as abundant as lipid in liver from neonatal and adult animals. Lipid droplets of fetal liver were small to moderate in size and were contained within the hepatocyte cytoplasm (figs. 15, 16). Phenobarbital altered neutral lipid in liver from mice of day 19 of gestation and older. Liver sections from phenobarbital-treated animals contained lipid droplets in considerably greater density and the droplets were larger than in comparable controls (figs. 15, 16).

Total cellular lipid was measured in liver samples from fetal, pregnant and nonpregnant animals in order to determine if the observed histochemical differences in lipid droplet density between phenobarbital-treated and control animals were artifactual or real (table 1). Liver from fetal animals of day 19 of gestation which were treated with phenobarbital had significantly more $(\mathrm{P}<0.01)$ lipid than control animals. However, in fetal animals two days younger this difference could not be demonstrated. Since a difference in lipid density was observed in the histochemical analysis of liver from day 19 of gestation but not at earlier ages, these

TABLE 1

Dry weight of liver( $\mathrm{gm}$ )/gm wet weight of liver and $\mathrm{mg}$ of lipid/gm of dry weight of liver from adult mice at days 17 and 19 of pregnancy and their fetuses and from non-pregnant adult mice ${ }^{1}$

\begin{tabular}{|c|c|c|c|}
\hline Age group & Experiment & $\begin{array}{l}\text { gm dry weight of liver/ } \\
\text { gm wet weight of liver }\end{array}$ & $\begin{array}{l}\text { mg cell lipid / } \\
\text { gm dry weight of liver }\end{array}$ \\
\hline $\begin{array}{l}\text { Day } 19 \text { of } \\
\text { gestation }\end{array}$ & $\begin{array}{l}\text { treated } \\
\text { control }\end{array}$ & $\begin{array}{l}0.484 \pm 0.01(16) \\
0.501 \pm 0.02(12)\end{array}$ & $\begin{array}{l}* * 61.24 \pm 2.6(16) \\
* * 46.40 \pm 2.9(12)\end{array}$ \\
\hline $\begin{array}{l}\text { Day } 17 \text { of } \\
\text { gestation }\end{array}$ & $\begin{array}{l}\text { treated } \\
\text { control }\end{array}$ & $\begin{array}{l}0.498 \pm 0.02(12) \\
0.467 \pm 0.02(11)\end{array}$ & $\begin{array}{l}50.09 \pm 4.4(12) \\
40.85 \pm 4.7(11)\end{array}$ \\
\hline $\begin{array}{l}\text { Day } 19 \\
\text { pregnant }\end{array}$ & $\begin{array}{l}\text { treated } \\
\text { control }\end{array}$ & $\begin{array}{l}0.654 \pm 0.02(12) \\
0.689 \pm 0.02(9)\end{array}$ & $\begin{array}{l}80.25 \pm 4.6(12) \\
73.42 \pm 6.1(9)\end{array}$ \\
\hline $\begin{array}{l}\text { Day } 17 \\
\text { pregnant }\end{array}$ & $\begin{array}{l}\text { treated } \\
\text { control }\end{array}$ & $\begin{array}{l}0.656 \pm 0.01(7) \\
0.656 \pm 0.01(8)\end{array}$ & $\begin{array}{l}70.79 \pm 7.5(7) \\
56.24 \pm 5.9(8)\end{array}$ \\
\hline $\begin{array}{l}\text { Non- } \\
\text { pregnant } \\
\text { adult }\end{array}$ & $\begin{array}{l}\text { treated } \\
\text { control }\end{array}$ & $\begin{array}{l}0.587 \pm 0.01(12) \\
0.592 \pm 0.01(12)\end{array}$ & $\begin{array}{l}* 95.53 \pm 4.7(12) \\
* * 66.97 \pm 3.3(12)\end{array}$ \\
\hline
\end{tabular}

I Statistical comparisons were made between values from animals which had received either phenobarbital or saline. The values are the means with standard error of the mean. The number of animals in each experiment is in parentheses.

$*, \mathrm{P}<0.001$. 
quantitative data were interpreted as verification of that observed difference.

Comparisons of the amount of lipid in livers from animals of either day 17 or 19 of pregnancy revealed that the quantitative changes between phenobarbital-treated and control animals were not significant $(P>$ 0.05 ) but were significantly different ( $P$ $<0.01$ ) in nonpregnant animals. This apparent lack of difference in pregnant animals is explained by the fact that the total wet weight of the liver increased significantly $(\mathrm{P}<0.01)$ in pregnant, phenobarbital-treated animals compared to pregnant controls (Preis et al., '66; Richards, '71) but this total increased change in weight is not reflected in table 1 because the data are expressed as milligram cellular lipid/gm dry weight where the dry weight represents a preweighed sample taken from the entire liver.

\section{DISCUSSION}

Phenobarbital accelerates the speed at which the liver can metabolize drugs (Conney and Burns, '63). This is a consequence of increased production of specific enzymes (Omura et al., '68) and the accompanying rapid proliferation of smooth endoplasmic reticulum (Jones and Fawcett, '66; Remmer and Merker, '65). The chemical components of liver studied in this paper are either bound to the smooth endoplasmic reticulum (NADPH diaphorase and glucose-6-phosphatase) (Fouts and Rogers, '65) or are closely related to its function (glucose-6-phosphate dehydrogenase) (Ballard and Hansen, '67).

The reactivity of the cells is dependent in part on their location within the lobule, i.e., pericentral cells had different enzyme profiles than periportal cells. Phenobarbital alters the density of the reaction products of the enzymes but does not change their basic pattern of distribution. Similar results have been obtained from rat liver (Koustaal and Hardonk, '69). Cells next to the central vein undergo greater proliferation of smooth endoplasmic reticulum after phenobarbital than do cells in the middle and outer third of the hepatic lobule (Becker and Lane, '68). Orrenius ('67) demonstrated that increased production of diaphorase consists first of enzyme synthesis and then incorporation of the enzyme into proliferating membranes. Since diaphorase is bound to the smooth endoplasmic reticulum and its increased production in response to the drug has been measured biochemically (Dallner et al., '66b; Jick and Shuster, '66), one would expect a correlation between phenobarbital treatment and increased enzyme activity in cells with rapid proliferation of smooth endoplasmic reticulum.

Changes in glucose-6-phosphate dehydrogenase after phenobarbital may be the result of stimulated pentose shunt activity in which accelerated amounts of NADPH are generated. Ballard and Hanson ('67) suggested that the marked speed of lipid synthesis in fetal liver is, in part, a function of NADPH provided by the pentose shunt pathway. Kato and Gillette ('65) showed that starvation may impair the metabolism of drugs by liver microsomes. This implies that starvation depletes the liver glycogen which would decrease glucose-6-phosphate available for pentose shunt activity; therefore, production of NADPH utilized for drug metabolism and lipid synthesis would proceed at a slower rate. Jones and Fawcett ('66) showed that depletion of glycogen occurs concurrently with the production of smooth endoplasmic reticulum.

It was demonstrated that phenobarbital given to adult mice results in apparent decreases in glucose-6-phosphatase activity, especially in the middle and inner third of the lobule, as compared to controls. This finding agrees with biochemical measurements of Orrenius et al. ('65). Synthesis of glucose-6-phosphatase is unaltered by the drug; yet it is tightly bound to the smooth endoplasmic reticulum which is undergoing rapid proliferation (Orrenius et al., '65). Since the cell volume increases in liver of phenobarbital-treated rats (Preis et al., '66), the net effect of these two processes is to decrease the content of the enzyme in the proliferating smooth endoplasmic reticulum.

An increased amount of neutral linid in fetal liver after phenobarbital stimulation was observed at a stage of development coincident with the earliest time at which differences were observed in the density of reaction products of the en- 
zymes. These changes suggest that a correlation exists between the two events. This increase in lipid could not be demonstrated in day-17 fetal liver, indicating that in the two-day interval the fetal cells become competent to react to phenobarbital. The drug has been shown to increase the neutral lipid of liver and decrease the neutral lipid of the serum from the adult mouse (Salvador et al., '70). It is not known if the action of the drug in liver is to block transport of neutral lipid out of the cell or to stimulate the production of additional neutral lipid within the cell.

Differences in response of liver from fetuses of different ages have been interpreted as reflecting diversities in the cellular make-up of the liver at various levels of maturation. In the normal development of liver from the fetal mouse the last three days of prenatal life are marked by the acquisition of moderate amounts of rough endoplasmic reticulum (Moule, '64). Alterations in the enzymes of fetal liver in response to the drug coincide with development of rough endoplasmic reticulum but occur prior to the time when a full complement of smooth endoplasmic reticulum can be observed ultrastructurally (Leskes et al,, '71). This does not preclude the possibility that phenobarbital induces the premature formation of some smooth endoplasmic reticulum. It is possible that phenobarbital altered some liver cells from fetal animals which were younger than day 19 of gestation but the histochemical methods used could not resolve this difference. We conclude that the response of fetal liver to phenobarbital is age-dependent and that the earliest fetal age in which observable changes can be seen is day-19 of gestation.

\section{LITERATURE CITED}

Ballard, F. J., and R. W. Hanson 1967 Changes in lipid synthesis in rat liver during development. Biochem. J., 102: 952-958.

Becker, F. F., and B. P. Lane 1968 Regeneration of the mammalian liver. VI. Retention of phenobarbital-induced cytoplasmic alterations in dividing hepatocytes. Am. J. Path., 52: 211225.

Conklin, J. L. 1966 Histochemical localization of enzymes in the embryonic chick liver. J. Exp. Zool., 161: 251-269.

Conniey, A. H., and J. J. Burns 1963 Induced synthesis of oxidative enzymes in liver microsomes by polycyclic hydrocarbons and drugs.
In: Advances in Enzyme Regulation. G. Weber, ed. Pergamon Press, New York, 1: 189-214.

Dallner, G., P. Siekevitz and G. E. Palade 1966a Biogenesis of endoplasmic reticulum membranes. I. Structural and chemical differentiation in developing rat hepatocyte. J. Cell Biol., 30: 73-96.

1966b Biogenesis of endoplasmic reticulum membranes. II. Synthesis of constitutive microsomal enzymes in developing nat hepatocyte. J. Cell Biol., 30: 97-117.

Dixon, R. L., and V. J. Willson 1968 Metabolism of hexobarbital and zoxazolamine by placentae and fetal liver supernatant fraction and response to phenobarbital and chlordane treatment. Arch. Int. Pharmacodyn. Ther., 172: 453-466.

Folch, J., M. Lees and G. H. S. Stanley 1957 A simple method for the isolation and purification of total lipides from animal tissues. J. Biol. Chem., 226: 497-509.

Fouts, J. R. 1965 The metabolism of drugs by the foetus. In: Symposium on Embryopathic Activity of Drugs. J. M. Robson, F. N. Sullivan and R. L. Smith, eds. J. and A. Churchill LTD, London, pp. 43-55.

Fouts, J. R., and L. A. Rogers 1965 Morphological changes in the liver accompanying stimulation of microsomal drug metabolizing enzyme activity by phenobarbital, chlordane, benzpyrene, or methylcholanthrene in rats. J. Pharmacol. Exp. Therap., 147: 112-119.

Holtzman, J. L., and J. R. Gillette 1966 The effect of phenobarbital on the synthesis of microsomal phospholipid in female and male rats. Biochem. Biophys. Res. Commun., 24: 639-643.

Jick, H., and L. Shuster 1966 The turnover of microsomal reduced nicotinamide adenine dinucleotide phosphate-cytochrome $\mathrm{C}$ reductase in the livers of mice treated with phenobarbital. J. Biol. Chem., 241; 5366-5369.

Jones, A. L., and D. W. Fawcett 1966 Hypertrophy of the agranular endoplasmic reticulum in hamsiter liver induced by phenobarbital (with a review on the function of this organelle in liver). J. Histochem. Cytochem., 14: 215-232.

Karnovsky, M. J., and S. R. Himmelhoch 1961 The use of ethylene diamine tetraacetic acid disodium in the histochemical demonstration of triphosphopyridine nucleotide-linked dehydrogenases. J. Histochem. Cytochem., 9: 203204.

Kato, R., and J. R. Gillette 1965 Effect of starvation on NADPH-dependent enzymes in liver microsomes in male and female rats. J. Pharmacol. Exp. Therap., 150: 279-284.

Koudstaal, J., and M. J. Hardonk 1969 Histochemical demonstration of enzymes related to NADPH-dependent hydnoxylating systems in rat liver after phenobarbital treatment. Histochemie, 20: 68-77.

Leskes, A., P. Siekevitz and G. E. Pallade 1971 Differentiation of endoplasmic reticulum in hepatocytes. I. Glucose-6-Phosphatase distribution in situ. J. Cell Biol., 49: 264-287.

Lillie, R. D. 1944 Various oil soluble dyes as 
fat stains in the super-saturated isopropanol technique. Stain Tech., 19: 55-58.

Moule, Y. 1964 Endoplasmic reticulum and microsomes of rat liver. In: Cellular Membranes in Development. M. Locke, ed. Academic Press, New York, pp. 97-133.

Omura, T., Y. Kuriyama, P. Siekevitz and G. E. Palade 1968 Effect of phenobarbital on the turnover of microsomal enzymes. In: Microsomes and Drug Oxidations. J. R. Gillette, A. H. Conney, G. J. Cosmides, R. W. Estabrook, J. R. Fouts and G. J. Mannering, eds. Academic Press, New York, pp, 475-493.

Orrenius, S. 1967 Liver enzyme-membrane responses in drug induction. In: The Interaction of Drugs and Subcellular Components in Animal Cells. P. N. Campbell, ed. J. and A. Churchill LTD, London, pp. 97-117.

Orrenius, S., J. L. E. Ericsson and L. Ernster 1965 Phenobarbital-induced synthesis of the micnosomal drug-metabolizing enzyme system and its relationship to the proliferation of endoplasmic membranes. J. Cell Biol., 25: 627-639.

Preis, C., S. Schaude and M. Siess 1966 Histo- metrische Analyse der Lebervergroberung nach chronischer Einwirkung von Barbituraten and Halothan. Arch. Pharmakol. exp. Path., 254: 488-504.

Remmer, H., and H. J. Merker 1965 Effect of drugs on the formation of smooth endoplasmic reticulum and drug-metabolizing enzymes. Ann. N. Y. Acad. Sci., 123: 79-97.

Richards, T. C. 1971 The effect of phenobarbital on some metabolic changes in developing mouse liver. Doctoral Dissertation. The University of Michigan, Ann Arbor, p. 71.

Salvador, R. A., C. Atkins, S. Haber and A. H. Conney 1970 Changes in the serum concentration of cholesterol, triglycerides and phospholipids in the mouse and rat after administration of either chlorcyclizine or phenobarbital. Biochem. Pharmacol, 19: 1463-1469.

Sperry, W. M. 1955 Lipide analysis. In: Methods of Biochemical Analysis. D. Glick, ed. Interscience Publishers, New York, 2: 83-111.

Washstein, M., and E. Meisel 1956 On the histochemical demonstration of glucose-6-phosphatase. J. Histochem. Cytochem., 4: 592. 
PLATE 1

EXPLANATION OF FIGURES

All photomicrographs on this plate are of sections of liver which demonstrate the activity of NADPH diaphorase. Figures 1 and 2 are from adult mice; figures 3 and 4 are from day 19 fetal mice.

1 Control. Note the more intensely reactive cells around the central veins of the liver lobules. $\times 60$.

2 Phenobarbital-treated. The arrows point to the boundaries of one hepatic lobule. Most of the cells in each lobule have deposits of reaction product within the cytoplasm. $\times 60$.

3 Control. A few scattered cells have dense deposits of reaction product in the cytoplasm. $\times 900$.

4 Phenobarbital-treated. The cytoplasm of many cells in the section are filled with enzyme reaction product. $\times 900$. 


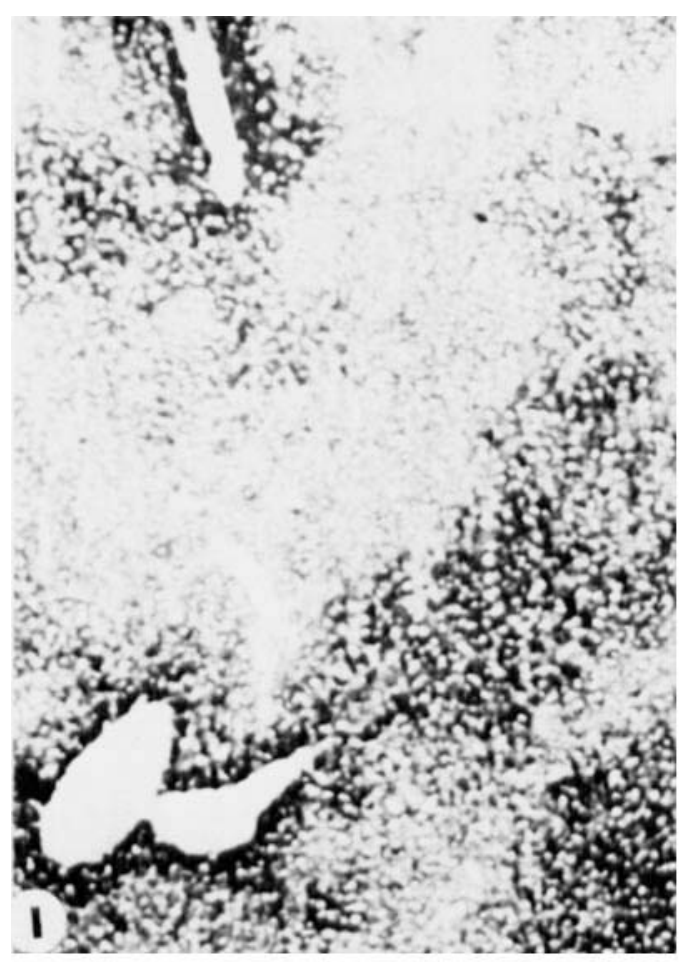

3.9. is H.3.5. Sot 20305 s

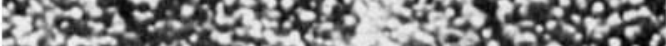

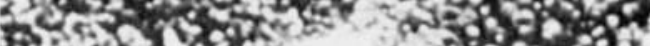
sकी

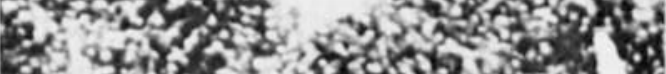

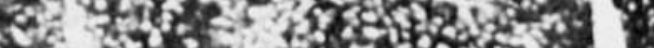

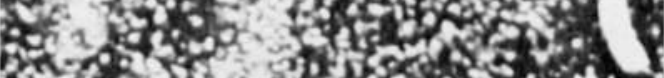

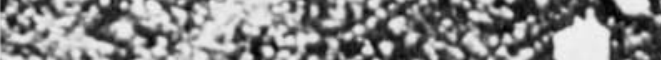

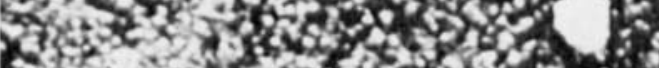
S. 2 .

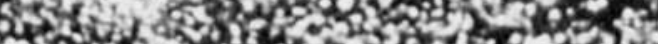

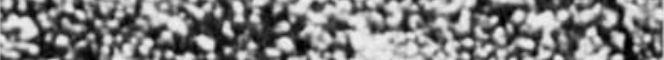

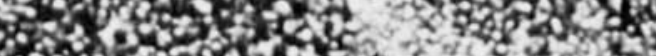

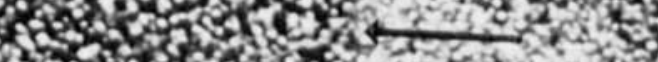

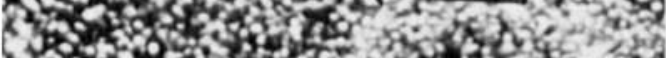

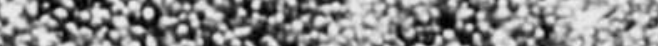
3620 s.

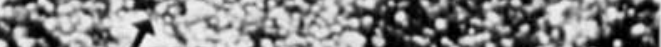

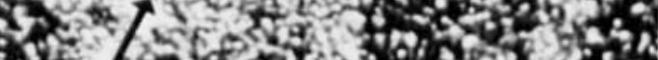

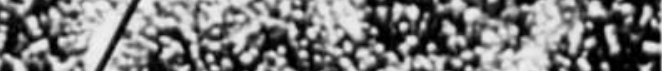

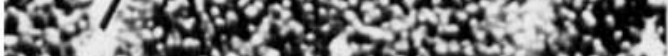

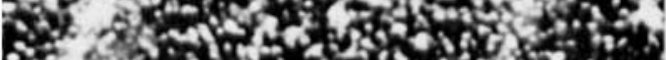

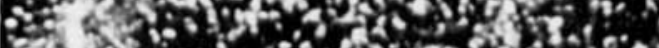
2 s
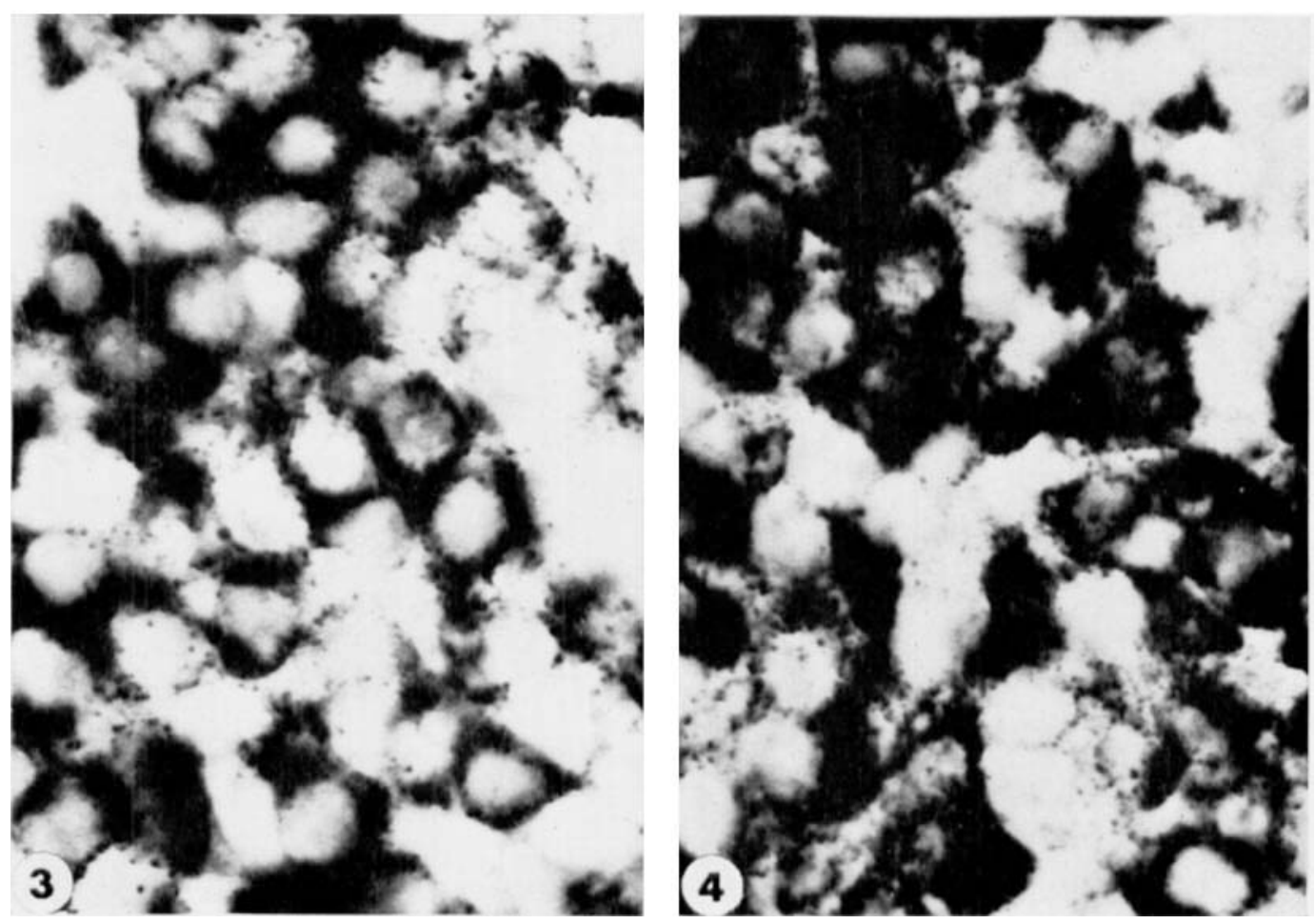
PLATE 2

EXPLANATION OF FIGURES

All photomicrographs on this plate are of sections of liver which demonstrate the activity of glucose-6-phosphatase. Figures 5 and 6 are from adult mice; figures 7 and 8 are from day 19 fetal mice.

5 Control. Notice the intensely reactive cells located in the outer zone of the lobules next to the portal canals. The deposits of lead sulfide form a wide band around the periphery of each lobule. $\times 60$.

6 Phenobarbital-treated. The intense enzyme activity localized around the portal canals (arrowheads) is not as apparent in this section as in figure 5. The liver cells have enlarged in size compared to the control liver. $\times 60$.

7 Control. Some cells have intense enzymatic activity while others are less reactive. $\times 200$.

8 Phenobarbital-treated. Deposits of lead sulfide can be seen in a few scattered cells of the section. $\times 200$. 

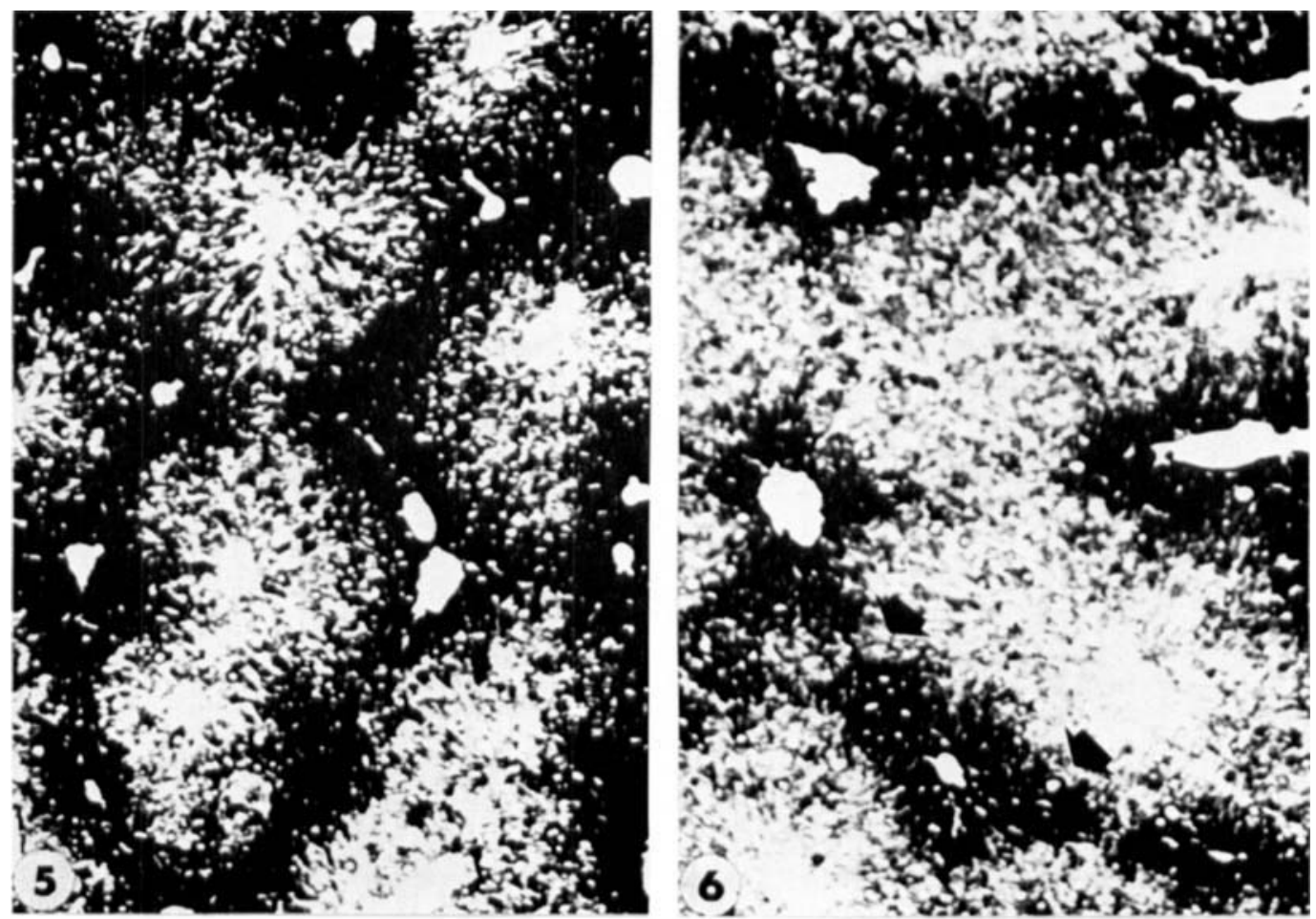

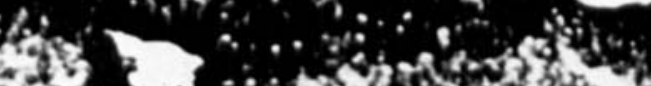

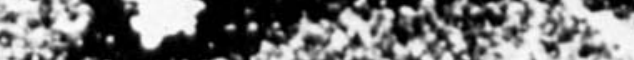

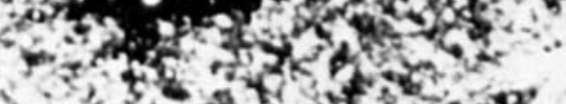

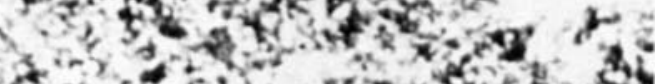

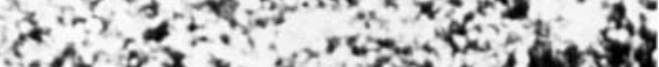

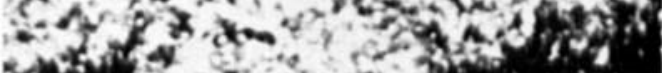

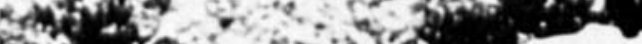
(6.

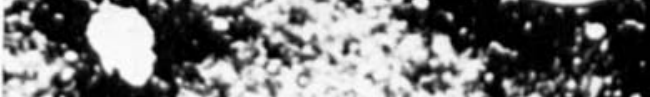

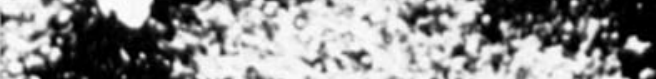

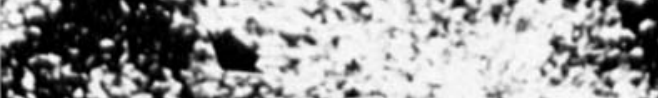

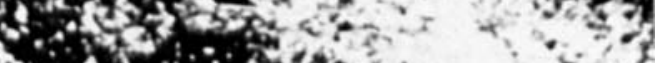

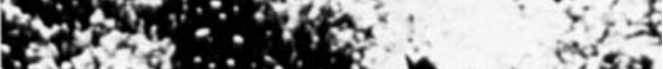

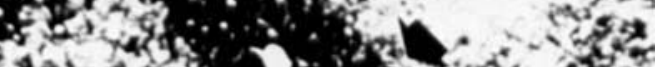
$-4 x^{2} \times 2$...

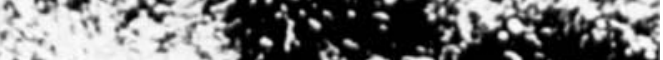

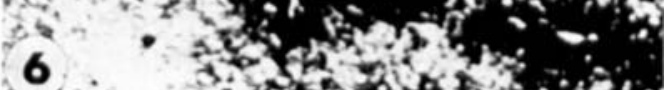
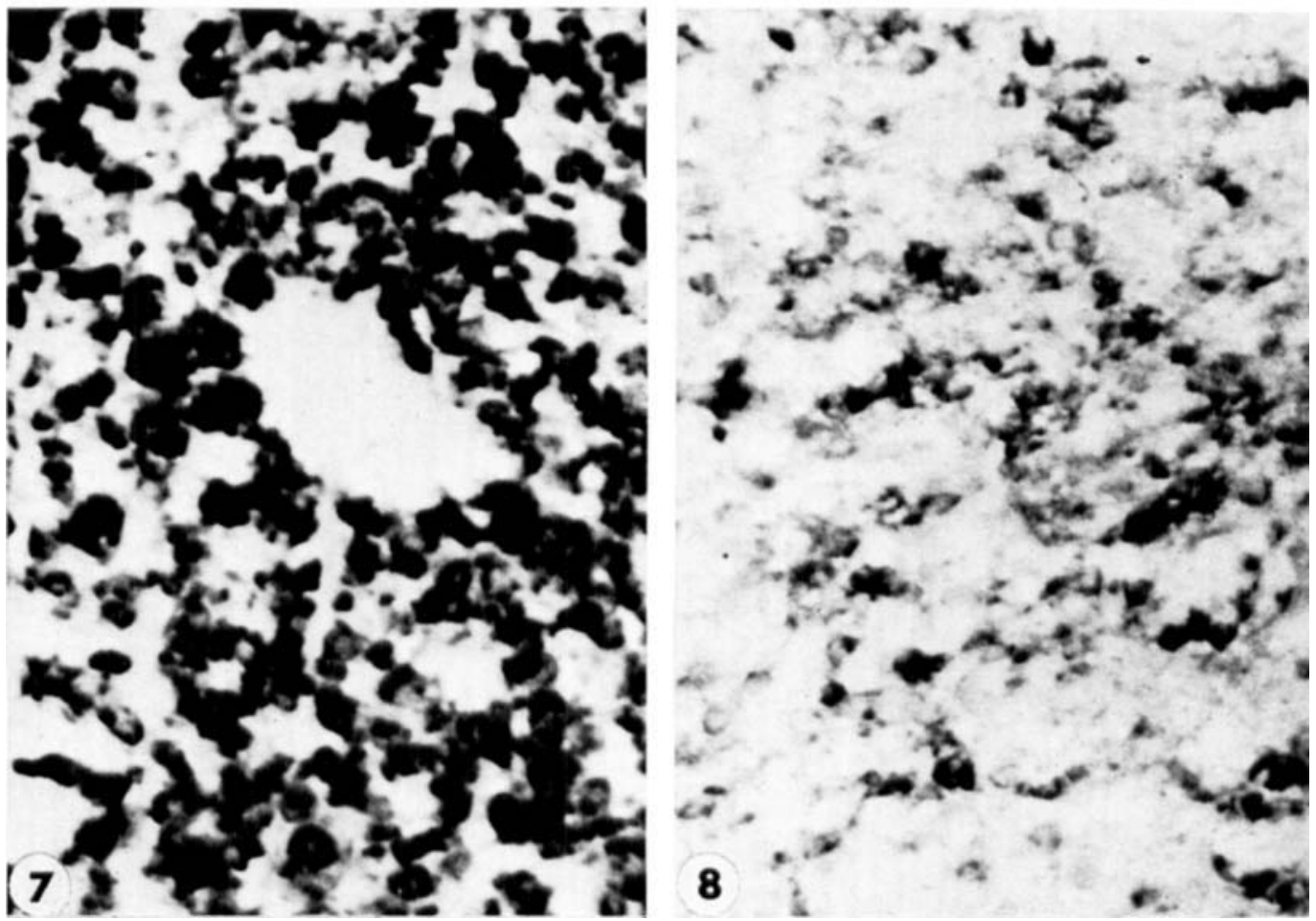
PLATE 3

EXPLANATION OF FIGURES

All photomicrographs on this plate are of sections of liver which demonstrate the activity of glucose-6-phosphate dehydrogenase. Figures 9 and 10 are from adult mice; figures 11 and 12 are from day 19 fetal mice.

9 Control. The reaction product in the cells next to the central vein (cv) is clearly more dense than in cells elsewhere in the lobule. $\times 200$.

10 Phenobarbital-treated. Intense deposits of diformazan are seen in many cells in the middle of the lobule as well as the inner zone. Compare the overall staining intensity with figure $9 . \times 200$.

11 Control. Some cells in the section have light to moderate amounts of reaction product. $\times 600$.

12 Phenobarbital-treated. Many cells in the section have dense deposits of diformazan. Arrow points to an intensely reactive cell. Compare with figure $11 . \times 600$. 
5 oritos

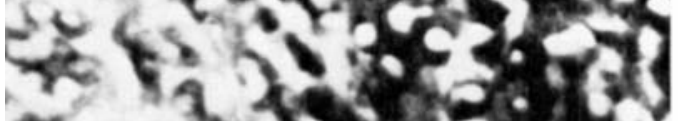

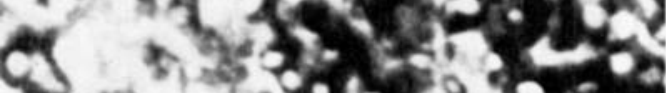

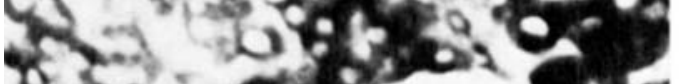

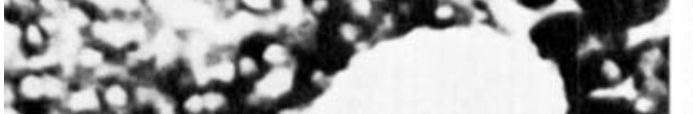

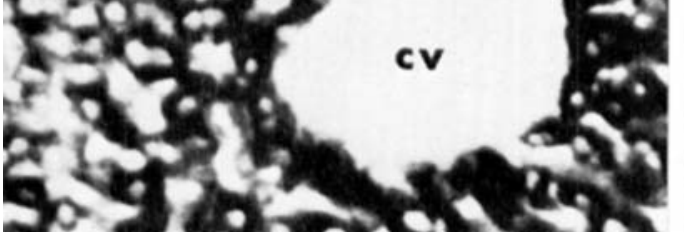

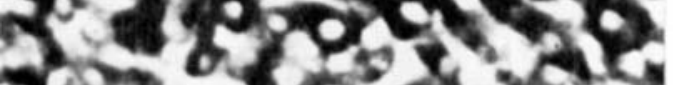
4 (A)

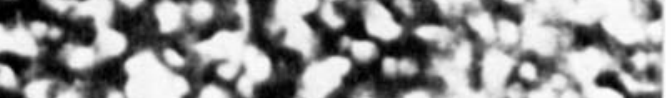

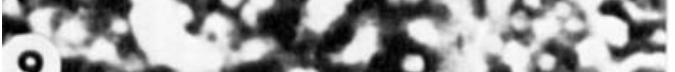

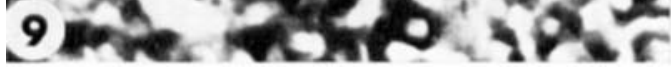

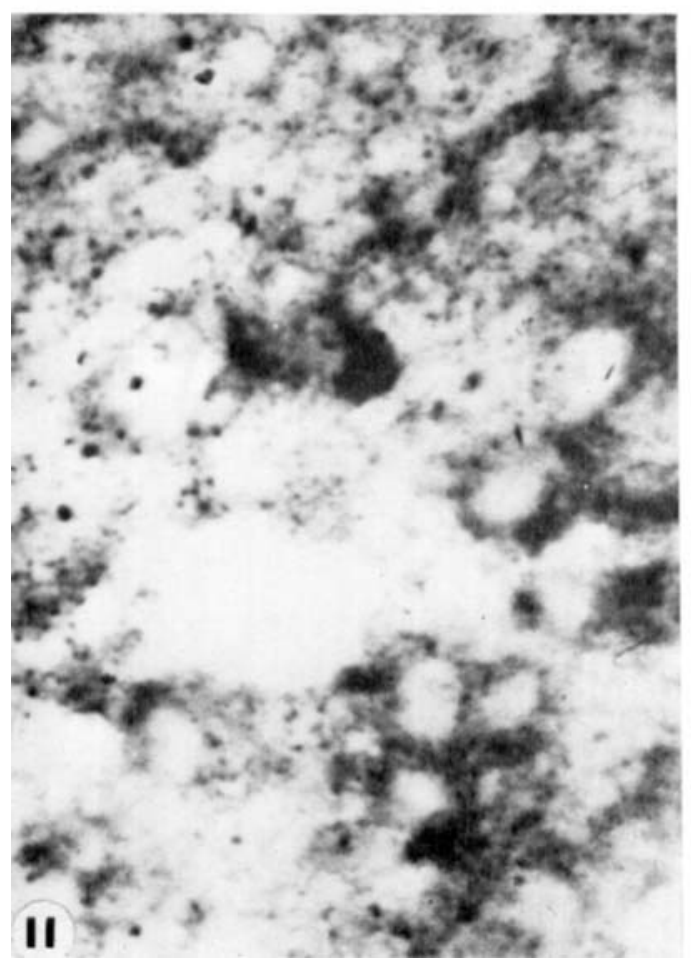

$28582 \times 1$ 6. 8.

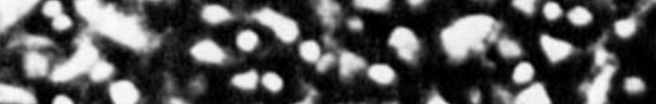

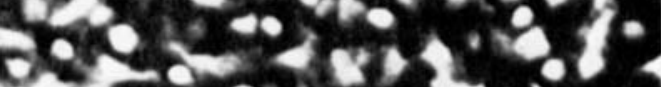
20

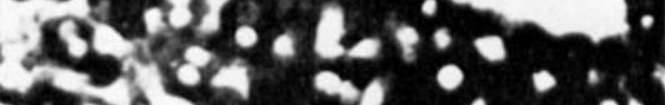

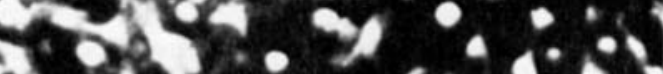
he
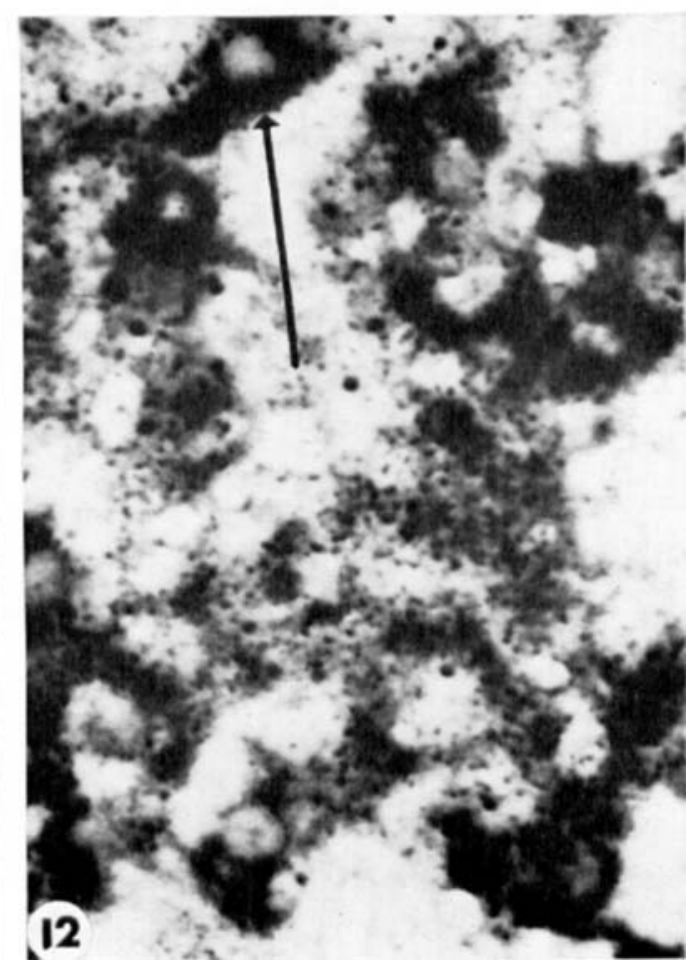


\section{PLATE 4}

EXPLANATION OF FIGURES

All photomicrographs on this plate are of sections of liver which demonstrate localization of neutral lipid with oil red $O$. Figures 13 and 14 are from adult mice; figures 15 and 16 are from day 19 fetal mice.

13 Control. The lipid droplets are abundant throughout the section. $\times 200$.

14 Phenobarbital-treated. The cells around the central vein (cv) of the lobule are clearly devoid of lipid while cells next to the portal canals have abundant lipid droplets. $\times 200$.

15 Control. Note the scarcity of lipid in the section. The intense darkly-staining cells are hematopoietic cells. $\times 600$.

16 Phenobarbital-treated. The arrow points to a single lipid droplet. Contrast the amount of lipid observed with that seen in figure 15. $\times 600$. 


\section{Thomas C. Richards}
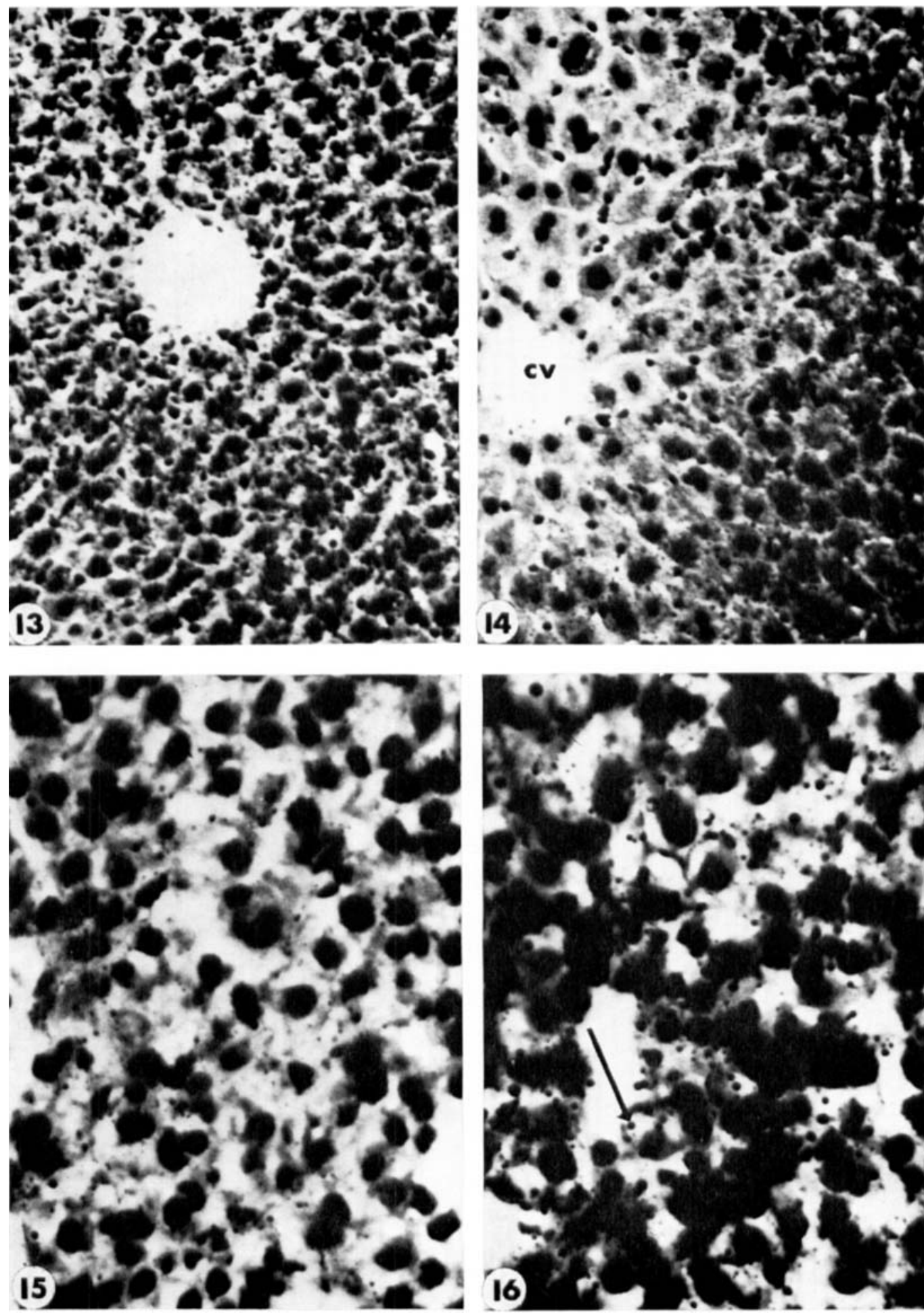

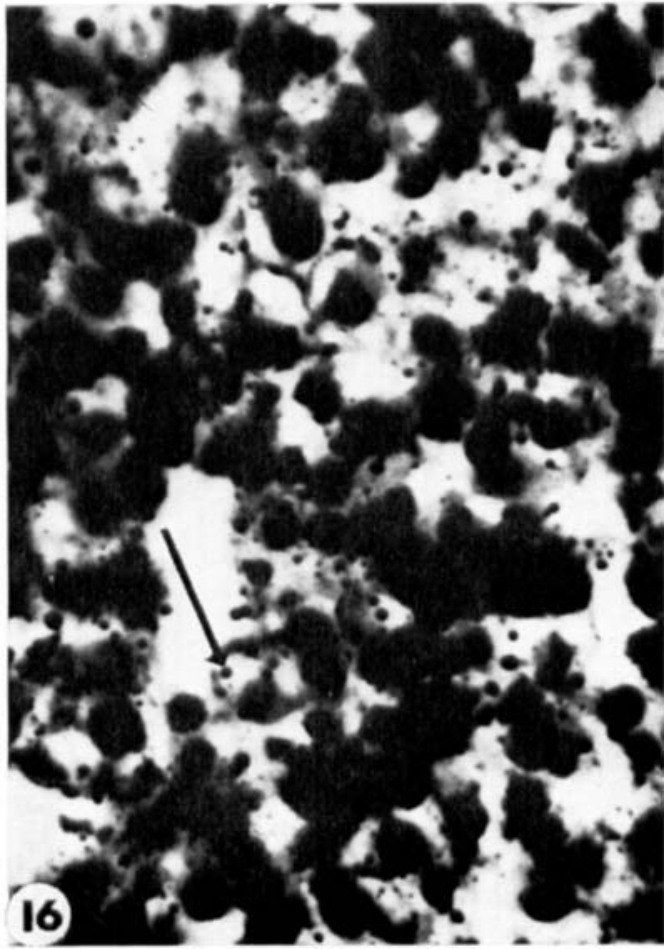

